\title{
Inter-Personal Trust, Transaction Cost and Livelihood Success of the Members in Community-Based Organizations ${ }^{1}$
}

\author{
H.M.S. Priyanath ${ }^{1}$ \& H.R.N.R. Habaragamuwa ${ }^{2}$ \\ ${ }^{1}$ Department of Economics \& Statistics, Sabaragamuwa University of Sri Lanka, \\ Belihuloya. \\ SRI LANKA \\ ${ }^{2}$ AHEAD DOR SUSL 47 Project, Department of Economics \& Statistics, \\ Sabaragamuwa University of Sri Lanka, Belihuloya. \\ SRI LANKA \\ priya@ssl.sab.ac.lk ${ }^{1}$
}

\begin{abstract}
This study attempted to study how interpersonal trust affects transaction costs and livelihood success of the members in community-based organizations (CBOs). Data were collected from 164 members of CBOs (76 from Samurdhi, 53 from Farmers' Organizations, and 35 from Sanasa) selected from three Divisional Secretariate Divisions in Ratanapura District. The data were collected by a structured questionnaire having the face to face interviews and analyzed using Partial Least Squire Structural Equation Modeling. The results revealed that interpersonal trust has a negative influence on TC and it has a positive influence on the livelihood success of the members in CBOs. The results further confirmed that transaction costs play a mediator role in the relationship between interpersonal trust and the livelihood success of the members in CBOs. Thus, the study makes important contributions to the literature by providing empirical evidence related to the role of interpersonal trust on TC and the livelihood success of the members in CBOs.
\end{abstract}

Keywords: Community-Based Organizations, Livelihood, Inter-Personal Trust, Transaction Cost.

\section{INTRODUCTION}

Community-based organizations (CBOs) are not for profit, organizations on a local and national level, facilitating community efforts for community development (Hussain, Khattak \& Khan, 2008). CBOs work through people-centered modes of development such as availability of micro-finance, community participation in development ensuring community health education, and infrastructure improves over time. The purpose of CBOs is to improve the social and economic condition of members by providing technical and financial help to the communities

\footnotetext{
${ }^{1}$ Acknowledgments: This research was supported by the Accelerating Higher Education Expansion and Development (AHEAD) Operation of the Ministry of Higher Education funded by the World Bank.
} 
(Hussain, Khattak \& Khan, 2008). Scholars highlighted that performance of CBOs depends on the voluntary base collective action of the members and the strength of the social capital among them the members (Haque, 2007). The powerful dimension of social capital is considered as interpersonal trust developed among members over a period with regular interaction. Inter-personal trust, often characterized by a variety of elements such as strong bonds, information sharing credibility, and other special characteristics that develop among a group of people due to maintaining long term relationships (Bromiley \& Harris, 2006). The importance of these characteristics of a relationship has been widely recognized as a dominant paradigm in investigating the impact of socially embedded qualities on economic development. Important dimensions of inter-personal trust include integrity, benevolence, ability, loyalty, etc. (Alzola \& Robaina, 2005; Butler and Butler \& Cantrell, 1984; Mayer, Davis \& Schoorman, 1995). This element is imperative at both individual and societal levels, and it is an important component for the smooth functioning of society, as it contributes to the development, maintenance, and sustainability of the social quality of people's lives (Mayer, et al., 1995). Moreover, as a core aspect of social capital, trust appears as a main driver of community development and influence greater livelihood outcomes (Yip, Subramanian, Mitchell, Lee, Wang, \& Kawachi, 2007) by providing effective protection against transaction cost and information asymmetry (Zaheer, McEvily \& Perrone, 1998; Priyanath \& Premaratne, 2017a).
Many scholars (Barney and Hansen, 1994; Gulati, 1995; Uzzi, 1997; Dyer, 1997) have highlighted that interpersonal trust influences mitigating transaction cost. Zaheer et al. (1998) highlighted that inter-personal trust among exchange parties mitigates the searching costs in exchange by allowing more open and honest sharing of information for a continuing relationship. Zaheer et al. (1998) have further argued that the relationship between inter-personal trust and contact costs is likely to be negative. When unforeseen contingencies arise from the external environment, such as costs not explicitly covered by the terms of a contract, high levels of trust facilitate the development of a common understanding about the contingencies and solve problems in a cooperative manner (Zaheer et al., 1998). Also, negotiations will likely be more efficient because the partner will have greater confidence that information provided by the other partner is accurate (Dyer, 1997). Under conditions of high trust, trading partners will spend less time and resources on monitoring to see if the other party is fulfilling the conditions of the agreement. If each exchange partner is confident that the other party will not be opportunistic, then both parties can devote fewer resources to monitoring. If trust is high then each party will assume that the other party is acting in good faith and will interpret behaviors more positively (Uzzi, 1997). Quality of relationship leads to mitigate opportunism on the one hand and avoid the breaking of the previous agreement (Gulati, 1995). More trusted exchange partners do not make mistakes in the transaction 
because a trusting relationship averts such behavior (Dyer, 1997). Therefore, time and money for monitoring transactions should not be incurred (Gulati, 1995a; Barney and Hansen, 1994; Dyer, 1997). Sufficient evidence exists around the world that inter-personal trust improves economic efficiency by reducing transaction costs (Narayan \& Pritchett, 1997; Grootaert \& van Bastelaer, 2002). However, despite the growing literature on the influence of social capital, empirical evidence on the influence of interpersonal trust on transaction cost and the livelihood outcomes of the members in community-based organizations in Sri Lanka is largely scarce. The limited knowledge about the SC which is developed by CBOs and the impact of SC on transaction cost and livelihood improvement was a major problem to understand the implications of SC in a different social context. Therefore, this paper attempts to explore empirically how does inter-personal trust affects the transaction cost and livelihoods of the members in CBOs in Sri Lanka. The remainder of the paper is organized as follows: The first section provides the background, research problem and objectives. The second part reviews the theoretical background and hypotheses are presented in the third section. The research methodology used are presented in the fourth step and the results are presented the section five. Finally, the study concluded, as well as the implications are presented.

\section{THEORETICAL BACKGROUND}

This section reviews the theoretical background of the variables: interpersonal trust, transaction cost, and livelihood success.

Interpersonal Trust: Primarily, trust can be defined under two categories as interpersonal trust and interorganizational trust. Which, with the development of interpersonal trust, develops and generates interorganizational trust over time (Zaheer et al., 1998). In most of the relational models and social relationships, trust has been defined as a fundamental building block (Brashear et al., 2003; Chen and Barnes, 2007; Conway and Swift, 2000; Morgan and Hunt, 1994), and a central element in the social exchange process (Hallen et al., 1991) and improve the performance of any entity (Chow and Chan, 2008). Universally, trust can be defined as,

"Willingness of a party to be vulnerable to the action of another party based on the expectation that the other will perform a particular action important to the trustor, irrespectively of the ability to monitor or control that other party." (Huang and Dastmalchian, 2006, p.363)

Trust as a concept has a comprehensive sense of exchange relationships. It plays an important role in facilitating economic exchanges (Anderson and Weitz, 1989; Dwyer et al., 1987). Several studies have suggested that trust is better to commentate and treated as a 
multi-dimensional concept (Cannon \& William, 1999; Ganesan, 1997). Although, several factors have been proposed to represent the trust factor in the past literature. These scholars have identified benevolence (Alzola and Robaina, 2005; Cao and Zhang, 2011; Mayer et al., 1995), credibility (Alzola and Robaina, 2005; Cao and Zhang, 2011; Zaheer et al., 1998), and ability (Mayer et al., 1995) as the most appropriate dimensions to represent the trust factor.

According to Lindskold (1978), benevolence simply gives the meaning that the words of a person are trustworthy and correspond to their deeds, besides it does not necessarily mean giving something free to the other party. Typically, people may engage in an exchange, but they can have some underlying attachment to the trustor or a willingness to help each other (Mayer et al., 1995). That is, the trustee cares about the benefits for the trustor (Ganesan, 1994; Mayer et al., 1995). Instead, credibility mainly deals with promises among exchange partners. How far the engaging parties are capable of keeping promises to the other parties on exchange depends majorly upon the characteristics of the parties, and one's competency to guide others with better leadership (Rempel et al., 1985) can be explained as credibility. According to Mitchell et al. (2007) ability to trust, defines the willingness to share confidentiality between exchange partners. Moving forward, it has also been defined as the ability of a party to produce or to achieve desired outcomes. With some expectations of other scholars, the ability is a group of skills a party can have to perform a task successfully in any area. However, this should come with little aptitude, knowledge, training, experience, as well as a better communication competency (Mayer et al., 1995). As a set, these three dimensions appear to explain a major portion of trustworthiness. Each donates an exceptional viewpoint from which to consider the trustee, while this set provides a solid foundation to study trust among different parties.

Transaction Cost Theory: Williamson (1985) has defined transaction cost as a transfer of a good or service between technologically separable interfaces. An organization needs to incur costs for any economic transaction (Dyer, 1997). The producers should search for information about the lowest prices of inputs and the highest prices to sell their products to earn a profit. The cost incurred to find out the supplier who offers the lowest price is called the searching cost (Hobbs, 1996). Sometimes in a situation where both suppliers with a low material cost and a buyer offering a higher price are found, there is a certain occasion where there a request to provide goods the parties have to sign legally binding agreements or contracts which involves contractive cost or negotiation cost as there is a payment to be made to the lawyer and other payments (Hobbs, 1996; Williamson, 1985).

The exchange relationship consists of another cost and that is monitoring cost which is the cost concerning the monitoring of the organizational activities (Hobbs, 1996). The contract 
should be registered under government regulations and the cost involved in this process is identified as enforcement cost (Hobbs, 1996; Williamson, 1985). There are certain that has to be paid to the government when making a transaction that is also called enforcement cost which cost that emerges as a result of the transaction (Hobbs, 1996; Williamson, 1985). Thus, producers need to incur costs for searching buyers and suppliers, negotiating with exchange partners, long-term contracting, and monitoring the transaction agreements due to the asymmetrical information (Dyer, 1997; Hobbs, 1996; Williamson, 1985). Those costs are termed as transaction cost (Dyer, 1997; Williamson, 1985; Zhang, 2006). The main reason for transaction cost is the lack of information (Dyer, 1997; Zhang, 2006). If the information about suppliers who offer the lowest prices are readily available there is no reason to spend time and money searching for them and that reduces the cost.

Asymmetrical information blocks community members to make rational decisions which are called bounded rationality on the one hand and encourages exchange partners to behave opportunistically (opportunism) against the focal firm (Williamson, 1985). These reasons (bounded rationality and opportunism) appeared due to the asymmetrical information and therefore transactions tend to become costly. Therefore, TC is the costs incurred by a firm when using market mechanisms due to opportunism in the market and limitations of decision-makers in solving complex problems processing information (bounded rationality) (Zhang, 2009).

Livelihood Success: In most simple terms' livelihood can be explained as various activities that people likely to be involved in their day to day life to fulfill their necessities and desires. However, this does not mean involving only an income-earning activity but a wider range of activities such as dealing with hazards and vulnerabilities, having strong interactions within household members, different external parties, communities, and institutions while managing strong social networks (Beall and Kanji, 1999). From an individual or household livelihood perspective, livelihood is all about achieving necessities; finding food, water, shelter, and clothes for human survival. Even if livelihoods do not exclusively depend on money or income, it largely impacts on determining an individual's livelihood phases. Wealthy people are more probable to achieve their livelihood success than people who are termed as poor, as they can easily reach their needs, resources, knowledge, and skills under prevailing economic circumstances.

As Scoones (1998) concludes:

"The framework shows how, in different contexts, sustainable livelihoods are achieving through access to a range of livelihood resources (natural, economic, human and social capitals) which are combined in the pursuit of different livelihood strategies (agricultural intensification or extensification, livelihood diversification and migration)" 
To achieve sustainable livelihood, we must use remaining resources efficiently while using them most beneficially, for that institutions need to implement sound livelihood strategies to gain the most successful livelihood outcomes.

According to the sustainable livelihood analysis framework (Scoones, 1998), assets that influence livelihoods can be categorized into five major types named Human, Financial, Natural and Physical. Similarly, Moser (2006) has been identified this resource endowment includes two groups; tangible (natural, financial) and intangible (human, social) assets. This asset-based approach has been used by many scholars' (e.g. Scoones, 2009; Carney, 1998) in different contexts mainly in evaluating poverty, vulnerability, assessing livelihood strategies, risk management and improve livelihood outcomes. These effects would include gaining more income for the targeted population, better well-being, less vulnerability, better food security, more sustainable use of natural resources (Scoones, 2009).

Human Capital: In many recent studies human capital has been highlighted as a major driving force determining livelihood success (Mushongah \& Scoones, 2012; AvilaFoucat \& Rodríguez-Robayo, 2018). This is simply the labor resources included in households which have both qualitative and quantitative dimensions. Dimensions as household size, age, number of individuals engage in earning activities in a household can be defined under quantitative. Qualitative aspects mean the level of education, health care, population growth, urbanization, displacement and skill of the members of a community. Among all education is the priority factor among most of the communities.

Natural capital: Natural resources that are useful for maintaining improved livelihoods can be broadly classified into three main categories; Land resources, Water resources, and forest resources, as well this includes other environmental resources, especially general pool resources. In addition, it also means for investing, accumulating wealth and transferring it between generations. In reality, the natural capital of households includes much more than land and water. Specifically, wildlife is important not only for daily consumption and survival (López- Feldman, 2014) but also for diversification into wildlife tourism activities (Avila-Foucat et al., 2018) and other features of biodiversity.

Financial Capital: This explains the financial resources accessible to people which provide them with different livelihood options. Total income, credit accumulations, savings, subsidies, remittances and pensions are some of the major determinants of financial capital. In the absence of markets for financial intermediation, people save in the form of liquid assets such as cash balance, or lumpy property such as livestock for their future benefit (Devereux, 2001).

Physical Capital: Physical or produced capital is basic infrastructure (transportation, shelter, water, energy, communication) and production 
equipment and tools enable people to pursue their livelihoods. Physical capital is also related to the infrastructure necessary for agricultural production and transportation, along with household living conditions such as house infrastructure, appliances and basic needs (Ansoms \& McKay, 2012). Moreover, the hand tools and machinery necessary for productive activities are the variables used to describe physical capital. communications infrastructure, roads and distance to urban centers are critical to market and service access and are also can be included in this category (Riveros-Cañas, RodríguezRobayo, and Cesín, 2016).

Social Capital: Amongst all types of capital under livelihood assets social capital has been identified as an increasingly important aspect by scholars (Avila-Foucat \& RodríguezRobayo, 2018). Key aspects of this include cooperation among households (Mushongah \& Scoones, 2012) membership within different groups, institutional networks, relationships of trust, norms and reciprocity.

However, these concepts have never been extended to create activities of productive assets or economic returns. Such contributions will have a direct impact on improving the livelihood status of the people. Sen (1997) noted that the possession of human capital not only means that people produce more efficiently; It also gives them the ability to connect with the world more meaningfully. A social capital debate too helps in developing the SL framework, which helps to expand relationships between access, institutions and livelihoods. Thus, claim Serageldin and Steer, the notion of natural capital began to take a place, albeit subsidiary, alongside those of human and physical capital. On the one hand; each asset interacts with the others. Collaborations can also be devastating: when the investment of financial capital on the environment and social quality is harmful; Or where financial capital is produced in ways that reduce social capital (such as increasing inconsistencies, or promoting violence), weakening social networks through which people use different types of resources.

\section{HYPOTHESES}

This study analyses the impact of the relational aspect of social capital particularly inter-personal trust on transaction cost and livelihood success of the members in CBOs. Transaction cost economics as developed by Williamson (1985) focuses on the relationship between attributes of transactions and characteristics of the governance structures used to accommodate these transactions. A business firm needs to incur costs in searching for new buyers and suppliers, negotiating with exchange partners, long-term contracting and monitoring transaction agreements due to the asymmetrical information generated by imperfect market mechanisms (Dyer, 1997; Hobbs, 1996; Williamson, 1985). Those costs are termed as TC (Dyer, 1997; Williamson, 1985, 1985; Zhang, 2009). Further, Zaheer et al. (1998) have argued that the relationship between interpersonal trust $\mathrm{TC}$ to be negative. And trust in exchange 
relationships has been hypothesized to be a valuable economic asset because it has been described as an important antecedent to effective interorganizational collaboration.

A livelihood system is a dynamic realm that integrates both the opportunities and assets available to a group of people for achieving their goals and aspirations as well as interactions with and exposure to a range of beneficial or harmful ecological, social, economic and political perturbations that may help or hinder groups' capacities to make a living. Balatti \& Falk (2002) highlighted that CBOs lead to generating relational social capital among members. Because the relationship among members develops through frequent interaction, relational qualities including interpersonal trust and relational norms, collaborations, collective action among members develop with mutual understand (Abban et al., 2013). This study attempts to explore the nature of the relationship among inter-personal trust with $\mathrm{TC}$ and the livelihood success of the members in CBOs. The conceptual framework of this study is presented in figure 01 below. Based on the conceptual framework; the study constructed four hypotheses connecting those variables. According to the model, TC performs as a mediate variable between the independent variable (inter-personal trust) and the dependent variable (livelihood success of the members in CBOs).

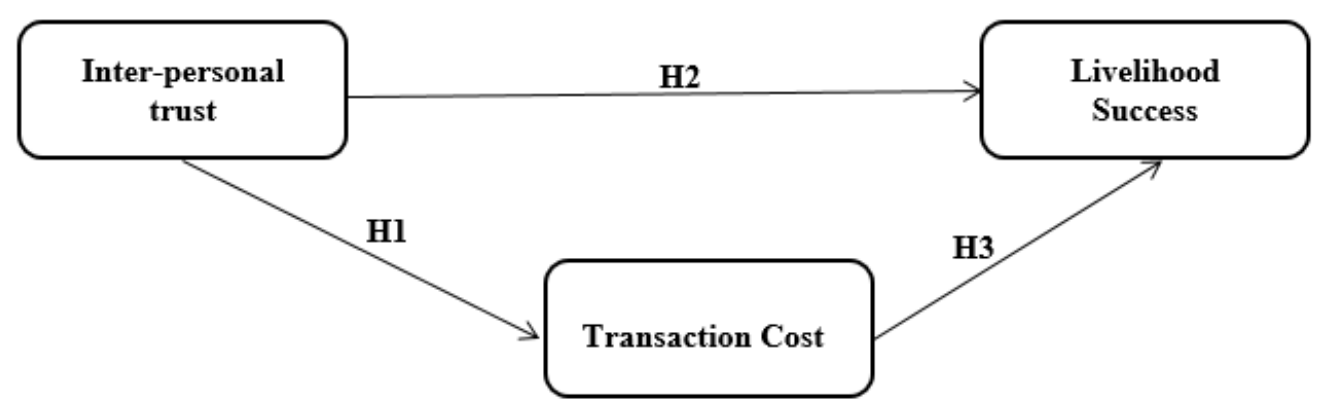

Figure 1. Conceptual Framework

\subsection{Interpersonal Trust and} Transaction Cost: A trust-based relationship is favorable to the finding of mutually beneficial, integrative solutions for unforeseen contingencies of the transaction and to reaching agreements quickly when transaction partners trust each other (Doucette, 1996). Interpersonal trust produces reliability that can eliminate unnecessary administrative processes to facilitate future transactions $(\mathrm{Gu}$ et al., 2008). Scholars have discovered that interpersonal-trust developed between exchange parties with continuous interaction is the most important element in mitigating the relational risk and opportunistic behaviors of exchange partners (Gambetta, 1998). Proving the above facts Dahlstrom and Nygaard (1999), with sufficient empirical evidence, 
clearly explained that opportunistic behavior increases TC continuously and trust mitigates the opportunism. Zaheer et al. (1998) highlighted that relational ties mitigate the searching costs in exchange by allowing more open and honest sharing of information for a continuing relationship. In addition, negotiations will likely be more efficient because the partner will have greater confidence that information provided by the other partner is accurate (Dyer, 1997). Under conditions of high trust, trading partners will spend less time and resources on monitoring to see if the other party is fulfilling the conditions of the agreement. If each exchange partner is confident that the other party will not be opportunistic, then both parties can devote fewer resources to monitoring. If trust is high then each party will assume that the other party is acting in good faith and will interpret behaviors more positively. Thus, this study predicts that:

H1 Interpersonal trust has a negative effect on the transaction cost of the members of $C B O$.

\subsection{Interpersonal trust and} livelihood success: Interpersonal trust is useful and significantly affects the livelihood success of the members of community-based organizations. Members can access and evaluate information which improves livelihood because of inter-personal trust between the member of CBOs and exchange partners which directly affects the reduction of information asymmetry and opportunism. Trusting information improves livelihood performance minimizing TC
(Gunasekara, Premaratne \& Priyanath, 2017). High trust relations imply more efficient exchange governance in the form of eased negotiations (Zaheer et al., 1998). As in literature, trust leads to enhance sustainable livelihoods through accessing information and resources (Priyanath \& Lakshika, 2020). Previous researchers have stated that SC including trust makes a positive relationship with household welfare especially in rural poor (Grootaert et al., 2002). Therefore, inter-personal trust becomes one of the important factors among livelihood successes in order to mitigate TC (Priyanath \& Lakshika, 2020). Thus, interpersonal trust facilitates the livelihood success of the members in CBOs. Therefore, the study proposes that:

H2 Interpersonal trust has a positive effect on the livelihood success of the members of $C B O$

\subsection{Transaction cost and livelihood success}

Williamson (1985) defined TC as a transfer of a good or service between technologically separable interfaces, and North (1990) described as the costs of measuring the valuable attributes of what is being exchanged and the costs of protecting rights and policing and enforcing agreements (Dahlstrom and Nygaard, 1999; Hobbs, 1996). Members of CBOs who involve in livelihood activities need to incur a cost for searching new buyers and suppliers, negotiating with exchange partners, long-term contracting and monitoring the transaction agreements due to the asymmetrical information generated in imperfect market mechanism (Dyer, 
1997; Hobbs, 1996; Williamson, 1985). Those costs are termed as TC which averts the livelihood success of the members in CBOs. TC may go high and it may significantly affect the economic performance (Priyanath \& Premarathna, 2017c). Priyanath \& Buthsala (2017) confirmed that a firm faced high transaction costs which discourages the firm's success. Yu, Zhu, \& Chen (2015) found that the minimizing TC of households will increase their performance. If $\mathrm{TC}$ is low, performance is higher. Therefore, the study assumes that:

H3 Transaction cost has a negative effect on livelihood success of the members of $C B O$

\subsection{Mediate role of transaction cost:}

The study discusses the relationship between the three variables as interpersonal trust and its impact on TC and livelihood success of CBOs. According to the conceptual framework, TC acts as the mediate variable between the dependent variable (livelihood success of the members in CBOs) and the independent variable (interpersonal trust). Under conditions of high trust, exchange partners will spend less time and resources on monitoring to see if the other party is fulfilling the conditions of the agreement. Interpersonal trust mitigates opportunism on the one hand and avoids the violation of the previous agreement on the other hand (Gulati, 1995). Therefore, developing a sound interpersonal trust always affects to mitigate transaction costs resulting from the success in livelihoods of the members in CBOs. Therefore, the study hypothesized that:
H4 Transaction cost has a mediate effect on the relationship between Interpersonal trust and Livelihood success of the members of $C B O$.

\section{MATERIALS AND METHODS}

This was a survey-based study in which members of community-based organizations in Ratnapura District in Sri Lanka were interviewed by using a structured questionnaire. The study mainly selects the quantitative approach to make valid statistical conclusions between the variables. In addition, the study obtains the support of a qualitative approach to validate the operational definitions and improve the operationalization of constructs and questionnaire items. In order to test the hypothetical relationships, the study carefully planned to collect accurate data to analyze the research problem in order to present the effect of interpersonal trust on TC and the livelihood success of the members of CBOs in Sri Lanka.

Key measures of inter-personal trust included were credibility (Ganesan, 1994; Zaheer et al., 1998), ability (Mayer et al., 1995) and benevolence (Ganesan, 1994; Mayer et al., 1995) in institutional networks. Accordingly, credibility is evaluated employing the components honesty, flexibility, fairness and the assurance that the member will in no circumstance purposely do anything to damage the relationship), and three items are used to measure benevolence - all of which have been adopted from Ganesan (1994); Zaheer et al. (1998).

The study measured TC at the unit level, adopting Williamson's (1985) classification i.e. searching costs, 
negotiation costs, monitoring costs and enforcement costs. Six items (adopted by Dyer and Chu, 2003) were used to measure searching cost. Five items adopted by Dyer and Chu (2003); were employed to measure negotiation cost. Four items (adopted by Dyer and Chu, 2003; Nguyen and Crase, 2011) were used to measure monitoring cost. Four items (adopted by Dyer and Chu, 2003) were used to measure enforcement cost. Livelihood Success: Livelihood success was measured based on five dimensions including physical capital, human capital, financial capital, natural capital and social capital (Gunasekara, Premaratne \& Priyanath, 2017).

The survey will be undertaken to ascertain the interpersonal trust, transaction cost and livelihood of the members of CBOs. To determine the success in livelihood, members of CBOs will be used as the unit of analysis. Therefore, the population of this study comprises the members of CBOs. In Sri Lanka, there is no accepted registered list of CBOs, but at least a few CBOs functions at the village level. Therefore, the study selected popular and common three CBOs Samurdhi, Sanasa and Farmers' Societies to collect data. The study randomly selects three Divisional Secretariate Divisions Imbulpe, Pelmadulla and Nivitigala in Ratnapura district in order to conduct the survey. Then, contact the DS of respective divisions and obtain the list of CBOs engaged in incomegenerating activities. Based on it, the study collects data from at least twenty members of each CBOs. Accordingly, 164 members of CBOs (76 from Samurdhi, 53 from Sanasa and 35 from Farmers' Society) were interviewed. The data collection tool used in the study is a structured questionnaire administered by an enumerator to individual respondent in the sample.

Partial Least Square - Structural Equation Modelling (PLS-SEM) was used to test the hypothetical relationships. The measurement model is evaluated employing reliability and validity tests and the efficiency of the structural model was evaluated by multi-collinearity issues, R2, effect size (f2) and predictive relevance (Q2). The smart PLS (version3) software was used to analyses data.

\section{RESULTS}

The measurement model was tested under PLS-SEM to establish the construct reliability and validity of the outer model. The overall assessment was done under two steps, as firstorder analysis and as the second-order analysis. As the first step, under firstorder analysis, reliability scores between questionnaire items with construct were generated. Table 01 proves that all generated outer loading values are above the minimum threshold criterion of 0.7 . On the other hand under the T-test, posits that factor loadings are statistically significant (all are above 1.96) at a 95\% confidence level demonstrating that altogether constructs under firstorder analysis satisfy the indicator reliability. Under internal consistency reliability, table 01 further depicts that both Cronbach's $\alpha$ and composite reliability values are above 0.7 . Then it can conclude the construct have internal consistency reliability as 
Cronbach's alpha and/or Composite reliability should be 0.7 or higher to have internal consistency reliability of a construct. Further, table 01 confirms the convergent validity of the firstorder constructs of the dependent variable as all the values are above 0.5 (AVE should be equal or greater than
$0.5)$. On the other hand, regarding the discriminant validity, the table 02 depicts that none of the inter-construct correlation values are above the square-root of the AVE and then this satisfies the criterion of the discriminant validity of first-order constructs.

Table 1. Analysis of the first-order constructs

\begin{tabular}{|c|c|c|c|c|c|}
\hline Construct & Loadings & $\begin{array}{c}\mathrm{t}- \\
\text { Statistics }\end{array}$ & $\mathbf{C R}$ & $\alpha^{*}$ & AVE \\
\hline \multicolumn{6}{|l|}{ 1. Livelihood Success (LS) } \\
\hline \multicolumn{3}{|l|}{ 1.1 Financial Capital } & 0.856 & 0.766 & 0.748 \\
\hline Increase secondary income due to $\mathrm{CBO}$ & 0.836 & 23.79 & & & \\
\hline Increase savings due to $\mathrm{CBO}$ & 0.893 & 57.09 & & & \\
\hline \multicolumn{3}{|l|}{ 1.2 Human Capital } & 0.966 & 0.957 & 0.825 \\
\hline $\begin{array}{l}\text { Improve professional knowledge due to } \\
\text { CBO }\end{array}$ & 0.959 & 192.34 & & & \\
\hline $\begin{array}{l}\text { Improve general knowledge due to } \\
\text { CBO }\end{array}$ & 0.879 & 52.38 & & & \\
\hline Improve skills due to $\mathrm{CBO}$ & 0.952 & 150.39 & & & \\
\hline $\begin{array}{l}\text { Increase experiences due to } \mathrm{CBO} \\
\mathrm{CBO}\end{array}$ & 0.816 & 23.40 & & & \\
\hline Improve efficiency due to $\mathrm{CBO}$ & 0.916 & 44.65 & & & \\
\hline \multicolumn{3}{|l|}{ 1.3 Natural Capital } & 0.923 & 0.834 & 0.857 \\
\hline $\begin{array}{l}\text { Sufficient water resources are available } \\
\text { for agriculture }\end{array}$ & 0.929 & 8.529 & & & \\
\hline $\begin{array}{l}\text { The risk of natural disaster is low in } \\
\text { this area }\end{array}$ & 0.923 & 8.767 & & & \\
\hline \multicolumn{3}{|l|}{ 1.4 Physical Capital } & 0.841 & 0.718 & 0.639 \\
\hline Increase water supply due to CBO & 0.756 & 14.83 & & & \\
\hline Increase building condition due to $\mathrm{CBO}$ & 0.858 & 32.97 & & & \\
\hline Increase land assets due to $\mathrm{CBO}$ & 0.781 & 13.34 & & & \\
\hline \multicolumn{3}{|l|}{ 1.5 Social Capital } & 0.886 & 0.758 & 0.648 \\
\hline $\begin{array}{l}\text { Increase the mutual corporation among } \\
\text { members of } \mathrm{CBO}\end{array}$ & 0.821 & 9.68 & & & \\
\hline $\begin{array}{l}\text { Increase the trusting relationship } \\
\text { among members due to CBO }\end{array}$ & 0.789 & 7.55 & & & \\
\hline
\end{tabular}




\begin{tabular}{|c|c|c|c|c|c|}
\hline \multicolumn{3}{|l|}{ 2.1 Ability } & \multirow[t]{3}{*}{0.893} & \multirow[t]{3}{*}{$\mathbf{0 . 8 2 1}$} & \multirow[t]{3}{*}{0.736} \\
\hline $\begin{array}{l}\text { I have confidence about the exchange } \\
\text { partners }\end{array}$ & 0.86 & 36.41 & & & \\
\hline $\begin{array}{l}\text { Exchange partners have much } \\
\text { knowledge regarding my capacity and } \\
\text { need }\end{array}$ & 0.832 & 31.38 & & & \\
\hline \multicolumn{3}{|l|}{ 2.2 Benevolence } & 0.892 & $\mathbf{0 . 8 3 8}$ & 0.673 \\
\hline $\begin{array}{l}\text { Exchange partners are giving higher } \\
\text { attention to my request }\end{array}$ & 0.829 & 30.78 & & & \\
\hline $\begin{array}{l}\text { Exchange partners are sacrifice time, } \\
\text { energy and resources to fulfill my } \\
\text { request }\end{array}$ & 0.827 & 28.61 & & & \\
\hline $\begin{array}{l}\text { They always ready and willing to offer } \\
\text { me their assistance and support at any } \\
\text { time }\end{array}$ & 0.847 & 31.73 & & & \\
\hline \multicolumn{3}{|l|}{2.3 Creditability } & 0.964 & 0.953 & 0.842 \\
\hline Exchange partners are honest & 0.822 & 27.47 & & & \\
\hline Exchange partners can be trusted & 0.799 & 20.53 & & & \\
\hline $\begin{array}{l}\text { Exchange partners do not break the } \\
\text { previous agreement }\end{array}$ & 0.891 & 50.88 & & & \\
\hline Exchange partners are flexible & 0.846 & 37.60 & & & \\
\hline Exchange partners are honest & 0.857 & 42.74 & & & \\
\hline \multicolumn{6}{|l|}{ 3. Transaction cost (TC) } \\
\hline \multicolumn{3}{|l|}{ 3.1 Searching Cost } & & & \\
\hline $\begin{array}{l}\text { Labor cost for searching exchange } \\
\text { partners }\end{array}$ & 0.941 & 135.72 & & & \\
\hline $\begin{array}{l}\text { Traveling cost for searching exchange } \\
\text { partners }\end{array}$ & 0.897 & 56.81 & & & \\
\hline $\begin{array}{l}\text { Communication cost for searching } \\
\text { exchange partners }\end{array}$ & 0.925 & 105.92 & & & \\
\hline $\begin{array}{l}\text { Time cost for searching exchange } \\
\text { partners }\end{array}$ & 0.929 & 101.42 & & & \\
\hline \multicolumn{3}{|l|}{ 3.2 Negotiation Cost } & 0.950 & 0.934 & 0.796 \\
\hline $\begin{array}{l}\text { Labor cost for negotiation with } \\
\text { exchange partners }\end{array}$ & 0.918 & 65.07 & & & \\
\hline $\begin{array}{l}\text { Traveling cost for negotiation with } \\
\text { exchange partners }\end{array}$ & 0.936 & 109.29 & & & \\
\hline $\begin{array}{l}\text { Communication cost for negotiation } \\
\text { with exchange partners }\end{array}$ & 0.761 & 21.49 & & & \\
\hline $\begin{array}{l}\text { Time cost for negotiation with } \\
\text { exchange partners }\end{array}$ & 0.932 & 114.89 & & & \\
\hline \multicolumn{3}{|l|}{ 3.3 Monitoring Cost } & 0.960 & 0.945 & 0.858 \\
\hline Labor cost for monitoring transaction & 0.947 & 97.04 & & & \\
\hline $\begin{array}{l}\text { Traveling cost for monitoring } \\
\text { transaction }\end{array}$ & 0.939 & 110.69 & & & \\
\hline
\end{tabular}




\begin{tabular}{|c|c|c|c|c|c|}
\hline $\begin{array}{l}\text { Communication cost for monitoring } \\
\text { transaction }\end{array}$ & 0.892 & 50.79 & & & \\
\hline Time cost for monitoring transaction & 0.926 & 74.29 & & & \\
\hline \multicolumn{3}{|l|}{ 3.4 Enforcement Cost } & 0.956 & 0.939 & 0.844 \\
\hline $\begin{array}{l}\text { Labor cost to resolve transaction } \\
\text { disputes }\end{array}$ & 0.906 & 58.24 & & & \\
\hline $\begin{array}{l}\text { Traveling cost to resolve transaction } \\
\text { disputes }\end{array}$ & 0.92 & 76.29 & & & \\
\hline $\begin{array}{l}\text { Communication cost to resolve } \\
\text { transaction disputes }\end{array}$ & 0.926 & 96.96 & & & \\
\hline $\begin{array}{l}\text { Time cost to resolve transaction } \\
\text { disputes }\end{array}$ & 0.923 & 91.92 & & & \\
\hline $\begin{array}{l}\text { Labor cost to resolve transaction } \\
\text { disputes }\end{array}$ & 0.906 & 58.24 & & & \\
\hline
\end{tabular}

*Cronbach's $\alpha .(n=164)$.

Source: Survey data, 2020.

Table 2. Discriminant validity of first-order constructs

\begin{tabular}{|l|c|c|c|c|c|c|c|c|c|c|c|c|}
\hline & 1 & 2 & 3 & 4 & 5 & 6 & 7 & 8 & 9 & 10 & 11 & 12 \\
\hline 1. FC & $\mathbf{0 . 8 6 4}$ & & & & & & & & & & & \\
\hline 2. HC & .665 & $\mathbf{0 . 9 0 8}$ & & & & & & & & & & \\
\hline 3. NC & .328 & .269 & $\mathbf{0 . 9 2 5}$ & & & & & & & & & \\
\hline 4. PC & .616 & .509 & .490 & $\mathbf{0 . 7 9 9}$ & & & & & & & & \\
\hline 5. SC & .252 & .257 & .225 & .216 & $\mathbf{0 . 8 0 5}$ & & & & & & & \\
\hline 6. Ability & .441 & .502 & .096 & .391 & .209 & $\mathbf{0 . 8 5 8}$ & & & & & & \\
\hline 7. Benevolence & .501 & .515 & .086 & .476 & .252 & .793 & $\mathbf{0 . 8 7 0}$ & & & & & \\
\hline 8. Creditability & .491 & .570 & .041 & .508 & .205 & .766 & .854 & $\mathbf{0 . 8 6 3}$ & & & & \\
\hline 9. Enforcement & .703 & .729 & .124 & .626 & .393 & .510 & .609 & .619 & $\mathbf{0 . 9 1 8}$ & & .909 & $\mathbf{0 . 9 1 7}$ \\
\hline 10. Monitoring & .728 & .732 & .051 & .580 & .263 & .526 & .631 & .656 & .892 & $\mathbf{0 . 9 2 6}$ & \\
\hline 11. Negotiating & .721 & .773 & .147 & .620 & .368 & .508 & .608 & .616 & .917 & .900 & $\mathbf{0 . 8 9 1}$ \\
\hline 12. Searching & .738 & .747 & .073 & .575 & .349 & .497 & .606 & .593 & .908 & .916 & .909 & \\
\hline
\end{tabular}
$(n=164)$.

Source: Survey data, 2020

The study measured the validity and reliability of five constructs of the dependent variable (LS) at the firstorder level. Based on the latent variable scores of first-order 
constructs, three constructs at the second-order level were formed under the dependent variable (LS). And same reliable and validity tests were conducted (See table 03). Accordingly, altogether indicator reliability of the ten latent variables, including three constructs under dependent variable (LS), four constructs under mediate variable (TC) and three constructs under independent variable (TRUST) at the second-order was evaluated.

According to table 03, all path coefficients (standardized factor loadings) were well above the threshold value of 0.7 . On the other hand, all the T-statistics are above 1.96 and it depicts that all are significant at $95 \%$ confidence levels. Table 03 further displays that Cronbach's $\alpha$ was higher than the required value of 0.7 and composite reliability was also higher than the recommended 0.7 value. With a higher level of Cronbach's $\alpha$ and composite reliability, second-order constructs were developed in a reliable manner. Further, the results confirm the convergent validity of the secondorder construct demonstrating the AVE above 0.5 .

Table 3. Analysis of the second-order construct

\begin{tabular}{|c|c|c|c|c|c|}
\hline Construct & Loadings & $\begin{array}{c}t- \\
\text { statistics }\end{array}$ & $C R$ & $\alpha^{*}$ & $A V E$ \\
\hline \multicolumn{3}{|c|}{ 1. Livelihood Success } & 0.891 & 0.816 & 0.731 \\
\hline $\begin{array}{l}\text { Financial } \\
\text { Capital }\end{array}$ & 0.895 & 52.793 & & & \\
\hline $\begin{array}{l}\text { Human } \\
\text { Capital }\end{array}$ & 0.864 & 34.354 & & & \\
\hline $\begin{array}{l}\text { Physical } \\
\text { Capital }\end{array}$ & 0.805 & 25.335 & & & \\
\hline \multicolumn{3}{|c|}{ 2. Inter personal Trust } & 0.952 & 0.925 & 0.869 \\
\hline Ability & 0.905 & 64.284 & & & \\
\hline Benevolence & 0.949 & 118.664 & & & \\
\hline Creditability & 0.942 & 112.664 & & & \\
\hline \multicolumn{3}{|c|}{ 3. Transaction Cost } & 0.984 & 0.978 & 0.938 \\
\hline Searching & 0.979 & 283.312 & & & \\
\hline Negotiating & 0.969 & 309.744 & & & \\
\hline Monitoring & 0.957 & 161.71 & & & \\
\hline Enforcement & 0.967 & 184.069 & & & \\
\hline
\end{tabular}

$(\mathrm{n}=164)$

Source: Survey data, 2020 
Then the discriminate validity of the second-order constructs is presented in table 04 and it shows that none of the inter-construct correlation values were above the square-root of the AVE and satisfied the criterion of the discriminant validity of the secondorder constructs.

Table 4. Discriminate validity of the second-order constructs

\begin{tabular}{|c|c|c|c|}
\hline Variable & LS & TC & TRUST \\
\hline LS & $\mathbf{0 . 8 5 5}$ & & \\
\hline TC & 0.837 & $\mathbf{0 . 9 6 8}$ & \\
\hline TRUST & 0.615 & 0.647 & $\mathbf{0 . 9 3 2}$ \\
\hline
\end{tabular}

Source: Survey data, 2020

The study assessed the multicollinearity of the structural model. It calculated VIF and tolerance level referring to the linear regression option in SPSS in order to check multicollinearity issues. Collinearity indicates that two constructs are measuring the same variable and it occurs when correlations among constructs are high (Hair et al., 2012). On considering the collinearity among the dependent variables in the structural model, VIF values of both TRUST and TC are 1.722 and Tolerance values are 0.581 for both variables. As VIF lower than the recommended threshold value 5 and the Tolerance value is higher than the recommended threshold value 0.2 for both TRUST and TC; so it can prove that there is no multicollinearity issues were detected among variables.

Then the study assessed the significance of the path coefficients. Path coefficients show how strong the effect of one variable is on another variable. Using $\beta$ value and $t-$

statistics, table 05 demonstrates the significance of path coefficients. In view of both path coefficients and $t-$ statistics, all hypothetical relationships were accepted. Considering the R2, LS has 71 percent of explanatory power. As the next step considering Q2, it resulted in the value as 0.515 which displays a substantial higher explanatory power.

Table 5. Path coefficients and hypotheses

\begin{tabular}{|l|c|c|c|}
\hline \multicolumn{1}{|c|}{ Hypotheses } & Path Coefficients & T Statistics & Decision \\
\hline TRUST $->$ TC & -0.647 & $13.11^{* *}$ & Accepted \\
\hline TRUST $->$ LS & 0.127 & $1.89^{*}$ & Accepted \\
\hline TC $->$ LS & -0.755 & $13.71^{* *}$ & Accepted \\
\hline
\end{tabular}

$(\mathrm{n}=164), \mathrm{R}^{2}=0.71, \mathrm{Q}_{2}=0.515$

Source: Survey data, 2020 
Finally, under the mediate effect (table 06), the coefficient of indirect effect takes -0.488 value and the coefficient under $\beta$ depicts 0.127 amount. As the t-statistic takes 1.89 it is significant under the
90\% confidence level. The VAF value reveals the strength of mediation. As it has taken 79.2 percent, a Complementary mediation of TC can be observed.

Table 6. Mediate Effect

\begin{tabular}{|c|c|c|c|c|c|c|c|c|}
\hline \multirow[t]{2}{*}{ Path } & \multicolumn{2}{|c|}{$\begin{array}{c}\text { Direct effect } \\
\text { model }\end{array}$} & \multirow{2}{*}{$\begin{array}{c}\begin{array}{c}\text { Indirec } \\
\text { t effect }^{5}\end{array} \\
a x b \\
\end{array}$} & \multirow{2}{*}{$\begin{array}{l}\mathrm{Se}_{\mathrm{d}}^{\mathrm{d}} \\
\text { (SD) } \\
\end{array}$} & \multirow{2}{*}{$\begin{array}{c}\text { t-stat }^{\mathrm{e}} \\
(a x b) / \mathrm{S}_{\mathrm{e}}\end{array}$} & \multirow{2}{*}{$\begin{array}{c}\begin{array}{c}\text { Total } \\
\text { effect }^{\mathrm{f}}\end{array} \\
(a \times b)+\mathbf{c}\end{array}$} & \multirow[t]{2}{*}{ VAF } & \multirow[t]{2}{*}{$\begin{array}{c}\text { Type of } \\
\text { mediation }\end{array}$} \\
\hline & $\beta^{a}$ & t-stat & & & & & & \\
\hline TRUST- LS (c) & 0.127 & 1.89 & $-0.488^{*}$ & 0.045 & 1.965 & -0.612 & -0.792 & $\begin{array}{l}\text { Complementary } \\
\text { mediation }\end{array}$ \\
\hline TRUST-TC (a) & -0.647 & 13.11 & & & & & & \\
\hline TC - LS (b) & -0.755 & 13.70 & & & & & & \\
\hline
\end{tabular}

Source: survey data, 2020

As the results depicted in Table 05, reveals that there is a significant negative direct relationship between interpersonal trust and transaction cost. (The path coefficient $=-0.647$ or 64.7 percent) And t-statistics (t-value = 13.11) show a significant negative relationship between interpersonal trust and transaction cost. The generated results address the hypothesis $\mathrm{H} 1$ accordingly and provided evidence that interpersonal trust has a negative effect on the transaction cost of the members of CBO. Some scholars have also provided similar results showing the relationship between inter-personal trust and various types of transaction costs shows a negative relationship. Zaheer et al. (1998) empirically found that interpersonal trust is associated negatively with the negotiation costs. Dyer and Chu (2003) empirically justified that the trust correlates inversely with the monitoring and the enforcement costs. Dyer and Chu (2003) explained that under the conditions of high trust among exchange partners will spend less time on exante contracting because they are confident that the payoffs will be fairly divided.

The theoretical relationship between interpersonal trust and the livelihood success of the members in CBOs was tested using the second hypothesis H2. The generated results depict that a direct positive relationship is there between TRUST and LS of the members in CBOs. (Path coefficient $=0.127$ or 12.7 percent $)$ It shows a positive relationship among TRUST and LS of the members in CBOs and according to the $\mathrm{t}$-statistic $(\mathrm{t}$-value $=1.89)$, it is 
significant under 0.10 significance level. Therefore, with reference to the study findings, it proves the second hypothesis; $\mathrm{H} 2$ interpersonal trust has a positive effect on livelihood success of the members of CBO. Abenakyo et al. (2007) found that interpersonal trust has the influence to improve livelihood.

Members of CBOs are unable to achieve their goals by themselves alone (Priyanath, 2017). To do so, they expect information, supports, resources and ideas from other members (Priyanath, 2017). Members of CBOs usually get support from other members to gather information, evaluate information, and get ideas and advice for their livelihood activities (Baker, 1990). Close members provide opportunities for interpersonal contact and lead to more positive feelings about providing supports, sharing information and resources with those with whom they develop a close relationship (Chow and Chan, 2008, Priyanath, 2017). Members of the CBOs who have strong trust would perceive greater social pressure for supporting and sharing their knowledge and information, because a good relationship based on trust results in high expectations of colleagues, including favorable actions (Chow and Chan, 2008). Thus, the members of CBOs have the ability to access information and get the support to evaluate information. As a result, the ability to improve the livelihood of the members of CBOs becomes improve.

As demonstrated in Table 05 above, there is a significant negative direct relationship between transaction cost and Livelihood success of the members in CBOs $(\beta=-0.755$ and $\mathrm{t}-\mathrm{value}=$ 13.707). As the path coefficient takes a negative value it proves that there is a negative relationship between TC and LS of the members in CBOs. Further, it describes that, if TC increases in one the LS of the members in CBOs will retard by 0.75 . According to the literature, it is proven that increase of TC influence to decrease the performance of a particular economic activity. Hennart (1993) mentioned if a firm minimizes the $\mathrm{TC}$, it has greater performance. Therefore, according to the study, it satisfies the hypothesis $\mathrm{H} 3$, TC has a negative effect on the livelihood success of the members of CBO.

According to table 06, it can observe the mediate effect of the transaction cost in between interpersonal trust and livelihood success of the members in CBOs. As per the findings of the study, it reveals that $\mathrm{TC}$ acts as the mediate variable between the independent (TRUST) and dependent variable (LS of members in CBOs). The 
results discussed above show that there is a significant impact of interpersonal trust on mitigating transaction costs and improving the success of livelihoods of the members in CBOs. A situation in which the VAF is larger than 20 percent and less than 80 percent could be characterized as a typical partial mediation (Hair et al., 2017), and VAF above 80 percent indicates a full mediation. Therefore, according to table 06, TC has a complementary mediation between the interpersonal trust and LS of the members in CBOs. Accordingly, the study reveals that interpersonal trust and transaction cost have an impact to achieve success in the livelihoods of the members of community-based organizations.

\section{CONCLUSION}

This study attempted to identify how interpersonal trust affects transaction costs and the livelihood success of the members in community-based organizations. The results revealed that interpersonal trust has strongly contributed to mitigate the TC and thereby enhance the livelihood success of the members in CBOs. The results further confirmed that interpersonal trust leads to decrease transaction cost showing a negative relationship between trust and TC. Further, the results confirm that interpersonal trust increases the livelihood success of the members in CBOs indicating a positive relationship between them. Moreover, TC plays a mediator role between interpersonal trust and the livelihood success of the members in CBOs. Thus, the study makes important contributions to the literature by providing empirical evidence related to interpersonal trust, TC and livelihood success of the members in CBOs. The study extends the understanding of the relative efficacy of social capital (inter-personal trust) and transaction cost economics into a different social and economic context. The study provides several valuable insights for policymakers revealing that livelihood success can be boosted by encouraging relational social capital (interpersonal trust) among members of CBOs because inter-personal trust facilitates livelihood success by mitigating TC. Interpersonal trust reflected by ability, benevolence and credibility will create a greater impact on reaping the success of livelihoods of the members in CBOs. Therefore, the study suggests policymakers to direct CBOs to arrange more activities to improve interpersonal trust among the members of CBOs. The study observes that most of the members of CBOs have developed close relationships with a few reliable members and exchange partners for regular transactions expecting to minimize TC. The study further suggests the members of CBOs to 
establish direct linkages among other associates to create a better relationship between $\mathrm{CBOs}$ and new exchange partners organizing network formation activities. However, future researches are recommended to carry out more researches on focusing the relational social capital, transaction cost and economic success of other economic sectors as well.

Acknowledgments: This research was supported by the Accelerating Higher Education Expansion and Development (AHEAD) Operation of the Ministry of Higher Education funded by the World Bank.

\section{REFERENCES}

Abban, R., Omta, S.W.F., Aheto, J. B. K. and Scholten, V.E. (2013). Connecting the dots: a multiple case study of the network relationships of small and medium-sized enterprises (SMEs) in the non-traditional agricultural export (NTAE) sector of Ghana. African Journal of Economic and Management Studies, 4(1), 74-94.

Alzola, L. M., \& Robaina, V. P. (2005). "Servqual: its applicability in electronic commerce B2C". Quality Management Journal, 12(4), 4657.

Anderson, E., \& Weitz, B. (1992). "The use of pledges to build and sustain commitment in distribution channels". Journal of
Marketing Research, 29(1), 1834.

Ansoms, A. \& McKay, A. (2012). A quantitative analysis of poverty and livelihood profiles: The case of rural Rwanda, Food Policy, 35(6),584-598. DOI: 10.1016/j.foodpol.2010.06.006

Avila-Foucat \& Rodríguez-Robayo, (2018). "Determinants of livelihood diversification: The case wildlife tourism in four coastal communities in Oaxaca, Mexico". Tourism Management. 69, 223-231, DOI: 10.1016/j.tourman.2018.06.021

Balatti, J., \& Falk, I. (2002). "Socioeconomic contributions of adult learning to the community: A social capital perspective". Adult Education Quarterly, 62, 281- 298.

Beall, J. \& Kanji, N., (1999). Households, livelihoods and urban poverty, Birmingham, UK: International Development Department, University of Birmingham.

Brashear, T., Boles, J., Bellenger, D., \& Brooks, C. (2003). "An empirical test of trust-building processes and outcomes in sales manager-salesperson relationships". Journal of the Academy of Marketing Science, 31(2), 189-200.

Bromiley, P. \& Harris, J. (2006). Trust, Transactions Cost Economics, and Mechanisms. Handbook of Trust Research: Edward Elgar. DOI: $10.4337 / 9781847202819.00014$ 
Butler, J., \& Cantrell, S. (1984). “A behavioral decision theory approach to modeling dyadic trust in superiors and subordinates". Psychological Reports, 4(2) 8089.

Carney, M. (1998). "The competitiveness of networked production: the role of trust and assets specificity". Journal of Management Studies, 35(4), 457479.

Cao, M., \& Zhang, Q. (2011).” Supply chain collaboration: Impact on collaborative advantage and firm performance". Journal of Operations Management, 29(3), 163-180.

Chen, Y. H., \& Barnes, S. (2007). "Initial trust and online buyer behavior". Industrial management \& data systems, 107(1), 21-36.

Chiles, T., \& McMackin, J. (1996). "Integrating variable risk preferences, trust, and transaction cost economics". The Academy of Management Review, 21(1), 73-99.

Chow, W., \& Chan, L. S. (2008). The social network, social trust and shared goals in organizational knowledge sharing. Information \& Management, 45(7), 458-465.

Coleman, J. (1988). "Social capital in the creation of human capital". Journal of Sociology, 94, 95120.

Conway, T., \& Swift, J. (2000). "International relationship marketing, the importance of psychic distance". European Journal of Marketing, 34(11/12), 1391-1414.

Dahlstrom, R. and Nygaard, A. (1999). "An empirical investigation of ex-post transaction costs in franchised distribution channels". Journal of Marketing Research, 36(2), 160170.

Devereux, S. (2001). "Livelihood Insecurity and Social Protection: A Re-Emerging Issue in Rural Development". Development Policy Review, 19(4), 507-519.

Doucette, W. R. (1996). "The influence of relational norms and trust on customer satisfaction in inter firm exchange relationship". Journal of Consumer Satisfaction, Dissatisfaction and Complaining Behaviour, 9(5), 95-103.

Dwyer, R., Schurr, P., \& Oh, S. (1987). "Developing buyer-seller relationships". Journal of Marketing, 51(2), 11-27.

Dyer, J. (1997). "Effective interim collaboration: how firms minimize transaction costs and maximize transaction value". Strategic Management Journal, 18(7), 535- 556.

Gambetta, D. (1988). Can we trust? New York: Blackwell.

Ganesan, S. (1994). Determinants of long-term orientation in buyerseller relationships. Journal of Marketing, 58(2), 1-19.

Ganesan, S., \& Hess, R. (1997). "Dimensions and levels of trust: 
Implications for commitment to a relationship". Marketing Letters, $8(4), 439-448$.

Gunasekara, R.W.M.N., Premaratne, S. P. \& Priyanath, H. M. S. (2017). "Impact of social capital on livelihood success of the members of community-based organizations in Sri Lanka", International Journal of Academic Research in Business and Social Sciences, 7(12), 1156 1167. DOI: 10.6007/IJARBSS/v7-i12/3746.

Grootaert, C., Bastelar, V. \& Thierry. (2002). "Understanding and Measuring Social Capital : A Multidisciplinary Tool for Practitioners. Directions in Development. Washington, DC: World Bank.

Hallen, L., Johanson, J., \& Mohamed, N. (1991). "Interfirm adaptation in business relationships". Journal of Marketing, 55, 29-37.

Haque, A.K.I. (2007). "Better Relationships, Enhanced Development: The Role of Social Capital and Community Based Organizations in Development for Rural Bangladesh". Master's Thesis, Lund University, Bangladesh.

Hobbs, J. (199). "A transaction cost approach to supply chain management". Supply Chain Management: An International Journal, 1(2), 15-27.

Huang, H. J., \& Dastmalchian, A. (2006). "Implications of trust and distrust for organizations: Role of customer orientation in a four- nation study". Personnel Review, 36(4), 361-377.

Hussain, A., Khattak, N. \& Khan, A.Q. (2008). "The role of community-based organizations in rural development: A case study of selected CBOs in district Swat". Sarhad Journal of Agriculture, 24(4), 149-154.

Lindskold, S. (1978). "Trust development, the GRIT proposal, and the effects of conciliatory acts on conflict and cooperation". Psychological Bulletin, 85(4), 772-793.

López- Feldman, A, (2014). "Shocks, Income and Wealth: Do They Affect the Extraction of Natural Resources by Rural Households?". World Development, 64(1), 91- 100.

Mayer, R., Davis, J., \& Schoorman, D. (1995). An integrative model of organizational trust. The Academy of Management Review, 20(3), 709-734.

Mitchell, P., Ferketich, S., \& Jennings, B. (2007). "Quality health outcomes model". Journal of Nursing Scholarship, 30(1), 4346.

Morgan, R., \& Hunt, S. (1994). "The commitment-trust theory of relationship marketing". Journal of Marketing, 50, 2038.

Mushongah, J. \& Scoones, I. (2012). "Livelihood Change in Rural Zimbabwe over 20 Years", The Journal of Development Studies, 48(9),

1241-1257, 
DOI:10.1080/00220388.2012.671 474

Narayan, D. \& Pritchett, L. (1997). "Cents and sociability: household income and social capital in rural Tanzania," Policy Research Working Paper Series 1796, The World Bank.

Nielson, C. (1998). “An empirical examination of the role of "closeness" in industrial buyerseller relationships". European Journal of Marketing, 32(5), 441 463.

doi.org/10.1108/0309056981021 5812

Priyanath, S., \& Premaratne, S. (2017). "The effect if interpersonal trust on transaction costs of owner-managed small enterprises in Sri Lanka". Sri Lanka Journal of Economic Research, 5(1), 1-29.

Priyanath, H. M. S., \& Buthsala, W. K. A. (2017). "Information, opportunism and business performance: A case of small businesses managed by women entrepreneurs in Sri Lanka". Asian Journal of Multidisciplinary Studies, 5(11), 330-339.

Priyanath, H.M.S. \& Lakshika, L.P.C. (2020). "Social Capital, Transaction Cost and Livelihood Success: A case of Samurdhi Community Based Organization in Sri Lanka", International Journal of Management Studies and Social Science Research, 2(2), $69-83$.

Priyanath H. M. S. (2017). "Effect of network structure on transaction cost of small enterprises in Sri Lanka: An empirical study". Journal of Small Business and Entrepreneurship Development, 5(1), 1-10. DOI: 10.15640/jsbed. v5n1a3.

Putnam, R. D. (1995). Making democracy work: Civic traditions in modern Italy. Princeton: Princeton University Press.

Rempel, J., Holmes, J., \& Zanna, M. (1985). "Trust in close relationships". Journal of Personality and Social Psychology, 49(1), 95-112.

Riveros-Cañas, Rodríguez-Robayo, \& Cesín, (2016). "The role of bromeliads in rural livelihoods: An experience in Oaxaca, Mexico". Journal of Sustainable Forestry, 35(6), 451-468. DOI: 10.1080/10549811.2016.1203338

Scoones, I., (1998). Sustainable Rural Livelihoods: A Framework for Analysis.

Scoones ， I. (2009). "Livelihoods perspectives and rural development", The Journal of Peasant Studies, 36(1), 171-196, DOI:

\subsection{0/03066150902820503}

Stone, W. \& Hughes, J. (2002). "Social capital; Empirical meaning and measurement validity". Australian Institute of Family Studies: Melbourne.

Svensson, G. (2004). "Vulnerability in business relationships: The gap between dependence and trust". Journal of Business \& Industrial Marketing, 19(7), 469 - 483. 
Williamson, O. (1985). The Economic Institutions of Capitalism: Firms, Markets, Relational Contracting. New York, NY: The Free Press.

Yip W, Subramanian SV, Mitchell AD, Lee DTS, Wang J, Kawachi I. (2007). "Does social capital enhance health and well-being? Evidence from rural China". Social Science \& Medicine, 64, 35 -49 .

Yu, C. J., and Liao, T., and Lin, Z. D. (2006). "Formal governance mechanisms, relational governance mechanisms, and transaction-specific investments in supplier-manufacturer relationships". Industrial Marketing Management, 35(2), 128- 139.
Zaheer, A., McEvily, B., \& Perrone, V. (1998). "Does trust matter? Exploring the effects of interorganizational and interpersonal trust on performance". Organization Science, 9(2), 141-159.

Zhang, F. (2006). "Information uncertainty and stock returns". The Journal if Finance, 61(1), 105-136. 